\title{
MENGUKUR DETERMINAN KINERJA USAHA KEDAI KOPI DI PANTAI INDAH KAPUK (PIK) JAKARTA DI MASA AWAL PANDEMI COVID-19
}

\author{
Greffin Geraldy Santoso ${ }^{1}$, Michael Christian ${ }^{2) *}$ \\ 1,2)Manajemen/Fakultas Sosial dan Humaniora, Universitas Bunda Mulia
}

Diterima 13 Agustus 2021 / Disetujui 3 September 2021

\begin{abstract}
The development of the Food \& Beverages $(F \& B)$ sector which encourages changes in the lifestyle of the people in Indonesia has contributed to the attractiveness of business in this sector. One of the interesting businesses in this sector is a coffee shop. The growth of this coffee shop business indirectly contributes to the national economy. Coffee consumption in Indonesia can also directly shape the pattern or lifestyle of consuming a variety of coffee, one of which is the style of consuming coffee in a coffee shop. This has also shaped the increase in the number of coffee shops in Indonesia. From an entrepreneurial perspective, this phenomenon is an opportunity that can be exploited. However, not all coffee shop entrepreneurs see this situation. With the existing phenomena, this study aims to analyze the performance of the coffee shop business using exogenous variables, namely market orientation, entrepreneurial orientation, and innovation. This research is a quantitative research using regression analysis using SPSS. The sample in this study was 75 coffee shop entrepreneurs in Pantai Indah Kapuk (PIK), Jakarta. The results of this study explain that all hypotheses are accepted. Market orientation in this case affects business performance. Likewise with the entrepreneurial orientation that affects business performance. Furthermore, innovation also affects business performance of coffee shops in this region. Simultaneously, each exogenous variable affects business performance at PIK. The overall results of this study are also still relevant and in line with several previous studies. From these results it can be explained that making strategies and making decisions that affect business performance. In addition, pay attention to competitors' strategies by understanding competitors' strengths and weaknesses. For further researchers, other additional variables that are not included in this study in determining business performance, such as the financial ability of businesses to survive or compete.
\end{abstract}

Keywords: business performance, market orientation, innovation

\begin{abstract}
ABSTRAK
Perkembangan sektor Food \& Beverages (F\&B) yang mendorong perubahan gaya hidup (lifestyle) masyarakat di Indonesia turut membentuk menariknya bisnis di sektor ini. Salah satu usaha yang menarik di sektor ini adalah kedai kopi (coffee shop). Pertumbuhan usaha kedai kopi ini secara tidak langsung memberikan kontribusi bagi perekonomian nasional. Konsumsi kopi di Indonesia juga secara langsung dapat membentuk pola atau gaya hidup mengkonsumsi kopi yang beragam, salah satunya gaya mengkonsumsi di kedai kopi. Hal ini yang juga membentuk peningkatan jumlah kedai kopi di Indonesia. Dari perspektif kewirausahaan, fenomena ini merupakan peluang yang dapat dimanfaatkan. Namun tidak se mua pelaku usaha kedai kopi melihat situasi ini. Dengan fenomena yang ada, penelitian ini bertujuan untuk menganalisis kinerja usaha kedai kopi dengan menggunakan variabel-variabel eksogen yaitu orientasi pasar, orientasi kewirausahaan dan inovasi. Penelitian
\end{abstract}

\footnotetext{
*Korespondensi Penulis:

E-mail: michaelchristianid@gmail.com
} 
ini merupakan penelitian kuantitatif dengan menggunakan analisis regresi menggunakan SPSS. Sampel pada penelitian ini sebanyak 75 pelaku usaha kedai kopi di Pantai Indah Kapuk (PIK), Jakarta. Hasil penelitian ini menjelaskan bahwa semua hipotesis diterima. Orientasi pasar dalam hal ini berpengaruh terhadap kinerja usaha. Begitu juga dengan orientasi kewirausahaan yang berpengaruh terhadap kinerja usaha. Selanjutnya, inovasi juga memberikan pengaruh terhadap kinerja usaha kedai kopi di wilayah ini. Secara simultan masing-masing variabel eksogen berpengaruh terhadap kinerja usaha di PIK. Keseluruhan hasil penelitian ini juga masih relevan dan sejalan dengan beberapa penelitian terdahulu. Dari hasil ini dapat dijelaskan bahwa membuat strategi dan mengambil keputusan yang mempengaruhi kinerja usaha. Selain itu, memperhatikan strategi pesaing dengan memahami kelebihan dan kekurangan pesaing. Bagi peneliti selanjutnya variabel-variabel tambahan lainnya yang tidak terdapat dalam penelitian ini dalam menentukan kinerja usaha, seperti kemampuan finansial usaha untuk bertahan maupun bersaing.

Kata Kunci: kinerja usaha, orientasi pasar, inovasi

\section{PENDAHULUAN}

Seiring perkembangan sektor
Food \& Beverages (F\&B) yang
mendorong perubahan gaya hidup
(lifestyle) masyarakat di Indonesia turut
membentuk menariknya bisnis di sektor
ini. Salah satu usaha yang menarik di
sektor ini adalah kedai kopi (coffee shop).
Pertumbuhan usaha kedai kopi ini secara tidak langsung memberikan kontribusi bagi perekonomian nasional. Hal ini menjelaskan bahwa adanya konsumsi kopi yang tinggi di Indonesia. Data dari International Coffee Organization (ICO) menunjukan bahwa konsumsi kopi di Indonesia secara rata-rata dalam 5 tahun terakhir kurang lebih sebesar 4.600 kantong (kapasitas 60 kilogram).

Tabel 1. Konsumsi Kopi Domestik Periode 2014-2019

\begin{tabular}{lll}
\hline Periode & Konsumsi* $^{*}$ & Rata-rata* $^{*}$ \\
\hline $2014-2015$ & 4.417 & \\
\hline $2015-2016$ & 4.550 & \\
\hline $2016-2017$ & 4.650 & \\
\hline $2017-2018$ & 4.750 \\
\hline $2018-2019$ & 4.800 & \\
\hline \multicolumn{2}{l}{ "kantong kapasitas 60 kg } & \\
\multicolumn{2}{l}{ Sumber: Annur (2020) }
\end{tabular}

Konsumsi kopi di Indonesia juga secara langsung dapat membentuk pola atau gaya hidup mengkonsumsi kopi yang beragam, salah satunya gaya mengkonsumsi di kedai kopi. Hal ini yang juga membentuk peningkatan jumlah kedai kopi di Indonesia. Toffin dan MIX MarcoMM SWA pernah menjelaskan melalui hasil riset yang dilakukan bahwa per Agustus 2019 terjadi peningkatan hampir 3 kali lipat dibandingkan tahun 2016 pada jumlah kedai kopi di Indonesia. Menariknya dijelaskan juga bahwa peningkatan dari 1.000 menjadi 2.950 kedai kopi itu memiliki market value yang besar mencapai Rp. 4,8 triliun (Dahwilani,
2019). Jakarta sebagai salah satu kota besar di Indonesia dimana pusat ragam bisnis tidak jarang membentuk tren atau gaya hidup termasuk dalam hal mengkonsumsi kopi di kedai kopi. Dengan persaingan usaha yang ada di Jakarta, salah satu strategi yang menentukan keberhasilan usaha dan perkembangan usaha adalah pemilihan lokasi usaha. Di antara banyaknya titiktitik kedai kopi di Jakarta, kawasan Pantai Indah Kapuk (PIK) hadir dengan menawarkan perkembangan wilayah yang memiliki daya tarik untuk mengembangkan usaha termasuk kedai kopi. Kawasan ini hadir dengan beragam konsep yang terintegrasi, mulai dari area 
hunian tempat tinggal sampai kepada Kawasan hiburan dan gaya hidup. Oleh karenanya, wilayah ini membentuk salah satu gaya hidup dalam mengkonsumsi kopi di kedai kopi khususnya bagi generasi muda.

Namun demikian, dari sisi bisnis, lokasi yang mendukung bukan menjadi faktor penentu satu-satunya dalam mendukung keberhasilan usaha kedai kopi di suatu wilayah. Kempa \& Setiawan (2019) melalui hasil penelitiannya pada usaha kafe di Ambon menjelaskan bahwa untuk membentuk keberhasilan persaingan yang unggul maka peranan orientasi kewirausahaan menjadi faktor penting yang harus diperhatikan. Selain orientasi kewirausahaan, Nadhar, Tawe, \& Parawansa (2017) menyatakan motivasi juga memegang peranan penting dalam performa usaha seperti kedai kopi di Makasar. Peranan kemampuan komunikasi khususnya melalui media sosial juga memengaruhi kinerja usaha kedai kopi di Jakarta Barat (Margasho \& Susanto, 2021). Namun demikian, sebagai suatu wilayah hiburan baru di Jakarta, kinerja usaha kedai kopi di wilayah ini perlu diukur lebih lanjut. Lokasi baru bukan hal yang mudah untuk mendapatkan keberhasilan usaha. Oleh karena itu penelitian ini bertujuan untuk menganalisis performa bisnis kedai kopi di PIK dengan menggunakan 3 variabel eksogen yaitu orientasi pasar, orientasi kewirausahaan, dan inovasi. Orisinalitas penelitian ini terletak pada penggunaan variabel-variabel kemampuan dalam penggunaan analisis aspek eksternal (orientasi pasar) dan aspek internal (orientasi kewirausahaan dan inovasi). Selain itu, pemilihan wilayah penelitian dimana merupakan wilayah baru yang memengaruhi atau membentuk gaya hidup masyarakat di Jakarta dapat memberikan kontribusi yang menarik untuk memperkaya hasil kajian-kajian penelitian yang sudah ada. Selain itu juga, waktu penelitian ini dilakukan di masa awal pandemic COVID-19 juga diharapkan dapat memberikan kontribusi yang lebih mendalam khususnya dalam memahami performa usaha kedai kopi di wilayah ini di masa sulit seperti pandemi.

\section{METODE PENELITIAN}

Penelitian ini merupakan penelitian kuantitatif dengan menggunakan analisis regresi. Alat analisis pada penelitian ini menggunakan SPSS 20. Alat analisis ini dapat mengakomodir mekalukan analisis regresi baik secara parsial maupun simultan. Instrumen pengukuran data pada penelitian ini menggunakan kuesioner yang didesain dengan skala ukur Likert 1 (Sangat Tidak Setuju) dan 5 (Sangat Setuju). Variabel penelitian ini terdiri dari 1 variabel endogen (kinerja usaha) dan 3 variabel eksogen (orientasi pasar, orientasi kewirausahaan, dan inovasi). Penelitian ini mengajukan 4 hipotesis (3 hipotesis parsial dan 1 hipotesis simultan), seperti yang ditunjukan model penelitian pada gambar 1 .

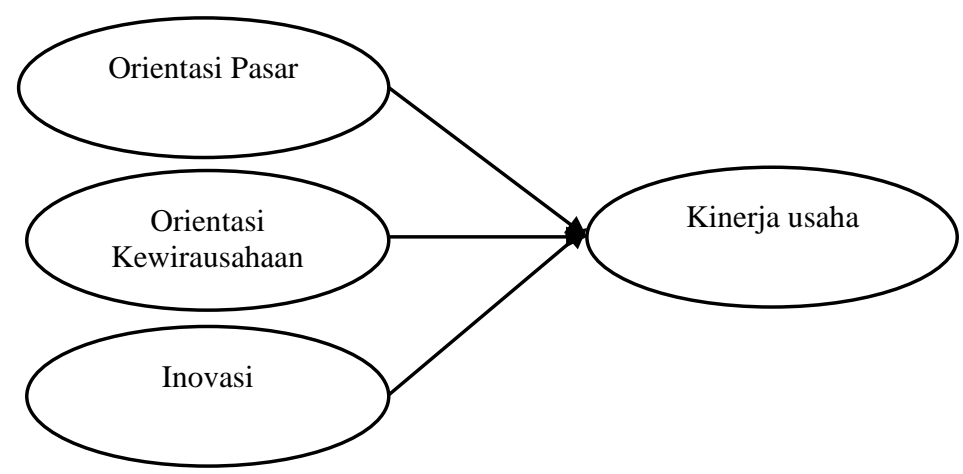

Gambar 1. Model Penelitian 
Hipotesis $(\mathrm{H})$ penelitian:

H1: Orientasi pasar berpengaruh terhadap kinerja usaha

$\mathrm{H} 2$ : Orientasi kewirausahaan berpengaruh terhadap kinerja usaha

H3: Inovasi berpengaruh terhadap kinerja usaha

H4: Orientasi pasar, Orientasi kewirausahaan dan Inovasi secara simultan berpengaruh terhadap kinerja usaha

Indikator-indikator pada pengukuran variabel-variabel pada penelitian ini mengadopsi pengukuran Buli (2017) yang terdiri dari kinerja usaha (penjualan, keuntungan, keuangan usaha), orientasi pasar (kepuasan pelanggan, responsif, customer value, analisis pesaing, komitmen), orientasi kewirausahaan (tindakan mengambil risiko, tindakan inovatif, keunggulan usaha dari pesaing, analisis peluang). Jumlah indikator

\section{HASIL DAN PEMBAHASAN}

\section{Profil Responden}

Tabel 2 menunjukan profil responden penelitian ini yang terdiri dari gender, usia, latar belakang pendidikan, posisi responden, jumlah tenaga kerja, pendapatan per bulan, dan lama usaha. Hasil ini menjelaskan bahwa responden laki-laki mendominasi penelitian ini sebesar $56 \%$ dan responden perempuan di bawah 50\%. Selanjutnya usia responden bisnis usaha kedai kopi di PIK memiliki latar belakang usia <30 tahun lebih dari $60 \%$ dan usia 30-50 tahun hampir mencapai 35\%. Responden pada penelitian ini juga didominasi oleh responden dengan latar belakang $\mathrm{S} 1$ (lebih dari 50\%), SMP-SMA lebih dari $21 \%$, diploma di bawah $20 \%$, dan paling kecil hampir mencapai $7 \%$ yaitu S2. Selanjutnya, melihat dari orang yang bertanggung jawab dalam menjalankan kedai kopi berdasarkan penelitian ini pada penelitian ini sebanyak 15 indikator. Selanjutnya populasi pada penelitian ini merupakan orang yang bertanggung atas strategi atau operasional kedai kopi di wilayak PIK. Kondisi pandemi mempengaruhi jumlah ketersediaan populasi yang ada karena tidak sedikit kedai kopi yang tidak beroperasi ataupun yang masih beroperasi. Oleh karena itu, penelitian ini menggunakan sampel. Ukuran sampel pada penelitian ini didasarkan dengan mengalikan jumlah indikator dengan 5 sampai dengan 10 (Hair, Black, Babin, \& Anderson, 2014). Dengan demikian, penelitian ini mengambil sampel paling sedikitnya 75 penganggung jawab kedai kopi. Dengan jumlah ini, waktu yang dibutuhkan untuk pengumpulan sampel disesuaikan hingga jumlah minimal sampel terpenuhi. Teknik sampling yang dilakukan pada penelitian ini menggunakan nonprobability sampling dengan random sampling.

dilakukan, dapat dijelaskan bahwa baik antara pemilik yang juga sebagai orang yang turun langsung untuk menjalankan kedai kopi ataupun dengan menunjuk orang lain sebagai penanggung jawab kedai kopi memiliki jumlah yang tidak berbeda jauh dimana masing-masing sebesar 46,67\% dan 53,33\%. Jumlah tenaga yang digunakan pada usaha kedai kopi pada penelitian ini didominasi 5-10 orang tenaga kerja yang mencapai $50 \%$ lebih dan paling rendah dengan jumlah tenaga kerja sebanyak lebih dari 10 tenaga kerja. Selanjutnya, dari aspek pendapat usaha didominasi dengan pendapatan Rp. 25-50 juta per bulan yang mencapai lebih dari $45 \%$ dan pendapatan di atas Rp. 50 juta hanya 21\%. Melihat dari tabel yang ada, usaha kedai kopi pada penelitian ini kurang dari 3 tahun (54\%), diikuti dengan lama usaha 3-5 tahun sebesar $37 \%$. 
Tabel 2. Profil Responden

\begin{tabular}{|c|c|c|}
\hline Profil & $\mathbf{N}$ & Persentase \\
\hline \multicolumn{3}{|l|}{ Gender } \\
\hline Laki-laki & 42 & $56 \%$ \\
\hline Perempuan & 33 & $44 \%$ \\
\hline \multicolumn{3}{|l|}{ Usia } \\
\hline$<30$ tahun & 49 & $65,33 \%$ \\
\hline 30-50 tahun & 26 & $34,67 \%$ \\
\hline \multicolumn{3}{|c|}{ Latar belakang pendidikan } \\
\hline SMP-SMA & 16 & $21,33 \%$ \\
\hline Diploma & 13 & $17,33 \%$ \\
\hline $\mathrm{S} 1$ & 41 & $54,67 \%$ \\
\hline S2 & 5 & $6,67 \%$ \\
\hline \multicolumn{3}{|l|}{ Posisi } \\
\hline Pemilik kedai kopi & 35 & $46,67 \%$ \\
\hline Manajer kedai kopi & 40 & $53,33 \%$ \\
\hline \multicolumn{3}{|l|}{ Jumlah tenaga kerja } \\
\hline$<5$ orang & 28 & $37,33 \%$ \\
\hline $5-10$ orang & 38 & $50,67 \%$ \\
\hline$>10$ orang & 9 & $12 \%$ \\
\hline \multicolumn{3}{|c|}{ Pendapatan per bulan (Rp) } \\
\hline$<25$ juta & 24 & $32 \%$ \\
\hline $25-50$ juta & 35 & $46,67 \%$ \\
\hline$>50$ juta & 16 & $21,33 \%$ \\
\hline \multicolumn{3}{|l|}{ Lama usaha } \\
\hline$<3$ tahun & 41 & $54,67 \%$ \\
\hline 3-5 tahun & 28 & $37,33 \%$ \\
\hline$>5$ tahun & 6 & $8 \%$ \\
\hline
\end{tabular}

Sumber: diolah penulis

\section{Uji reliabilitas dan validitas}

Tabel 3 menunjukan hasil reliabilitas masing-masing variabel pada penelitian ini. Reliabilitas variabel kinerja usaha, orientasi pasar, orientasi kewirausahaan dan inovasi menunjukkan hasil nilai lebih dari 0,6. Berdasarkan hasil ini maka dapat dijelaskan bahwa semua variabel dikatakan reliabel.

Tabel 3. Uji reliabilitas

\begin{tabular}{ll}
\hline Variabel & Cronbach's alpha \\
\hline Kinerja usaha & 0,718 \\
Orientasi pasar & 0,730 \\
Orientasi kewirausahaan & 0,686 \\
Inovasi & 0,707 \\
\hline \multicolumn{2}{l}{ Sumber: diolah penulis, SPSS, $\mathrm{n}=75$}
\end{tabular}

Selanjutnya, tabel 4 menunjukan hasil validitas masing-masing variabel. Berdasarkan hasil yang diperoleh maka dapat dijelaskan masing-masing variabel menunjukan nilai di atas 0,5. Dengan demikian, dapat dijelaskan bahwa seluruh variabel dikatakan valid. 
Tabel 4. Uji validitas

\begin{tabular}{ll}
\hline Variabel & Pearson correlation \\
\hline Kinerja usaha & 0,657 \\
Orientasi pasar & 0,632 \\
Orientasi kewirausahaan & 0,700 \\
Inovasi & 0,629 \\
\hline
\end{tabular}

Sumber: diolah penulis, SPSS, $\mathrm{n}=75$

\section{Uji asumsi klasik}

Pada uji asumsi klasik penelitian ini (tabel 5) terdiri dari uji normalitas, heteroskedastisitas dan multikolinieritas. Dari hasil ini dapat dijelaskan bahwa diketahui nilai signifikansi uji normalitas sebesar 0,933. Hasil ini lebih besar dari 0,05 dan dapat dijelaskan bahwa data terdistribusi normal. Selanjutnya, nilai signifikansi ketiga variabel eksogen pada uji heteroskedastisitas lebih dari 0,05.
Dengan demikian dapat dijelaskan pada model regresi tersebut tidak terjadi gejala heterokedastisitas. Uji asumsi klasik berikutnya yaitu uji multikolinieritas, dimana nilai Variance Inflation Factor (VIF) ketiga variabel yaitu Orientasi Pasar, Orientasi Kewirausahaan, dan Inovasi lebih kecil dari 10. Dengan hasil ini dapat dijelaskan bahwa antar variabel eksogen tidak terjadi multikolinearitas.

Tabel 5. Uji asumsi klasik

\begin{tabular}{ll}
\hline Uji & Hasil \\
\hline \multirow{2}{*}{ Normalitas } & Kolmogorov-Smirnov Test \\
& Asymp. Sig (2-tailed) $=0,933$ \\
\hline \multirow{3}{*}{ Heteroskedastisitas } & Spearman's rho - unstandardized residual \\
& Sig. orientasi pasar $=0,986$ \\
& Sig. orientasi kewirausahaan $=0,728$ \\
& Sig. orientasi inovasi $=0,968$ \\
\hline \multirow{3}{*}{ Multikolineritas } & Tolerance; VIF \\
& Orientasi pasar: Tolerance $=0,522 ;$ VIF $=1,916$ \\
& Orientasi kewirausahaan: Tolerance $=0,652 ;$ VIF $=1,534$ \\
& Inovasi: Tolerance $=0,481 ;$ VIF $=2,080$ \\
\hline Sumber: diolah penulis, SPSS, n=75
\end{tabular}

\section{Uji hipotesis}

Tabel 5 menunjukan hasil uji hipotesis pada penelitian ini. Berdasarkan hasil pada tabel ini dapat dijelaskan bahwa pada hipotesis 1 (H1), nilai t dan sig. menunjukan hasil lebih besar di atas 0,05. Dari hasil ini dapat dijelaskan juga bahwa hipotesis ini diterima. Dengan kata lain, hasil ini menjelaskan orientasi pasar berpengaruh terhadap kinerja usaha. Selanjutnya, pada hipotesis $2(\mathrm{H} 2)$, nilai $\mathrm{t}$ dan sig. juga menunjukan hasil lebih besar di atas 0,05. Dari hasil ini dapat dijelaskan juga bahwa hipotesis ini diterima. Dengan kata lain, hasil ini menjelaskan orientasi kewirausahaan berpengaruh terhadap kinerja usaha. Pada hipotesis 3 (H3), nilai $\mathrm{t}$ dan sig. juga menunjukan hasil lebih besar di atas 0,05. Dari hasil ini dapat dijelaskan juga bahwa hipotesis ini diterima. Dengan kata lain, hasil ini menjelaskan inovasi berpengaruh terhadap kinerja usaha. Pada hipotesis simultan (H4), nilai F dan sig. juga menunjukan hasil lebih besar di atas 0,05. Dari hasil ini dapat dijelaskan juga bahwa hipotesis ini diterima. Dengan kata lain, hasil ini menjelaskan bahwa orientasi pasar, orientasi kewirausahaan dan inovasi secara simultan berpengaruh terhadap kinerja usaha. 
Tabel 6. Uji hipotesis

\begin{tabular}{lll} 
Hipotesis & Hasil & Keterangan \\
\hline H1 & $\mathrm{t}=3,303 ;$ sig. $=0,003$ & H1 diterima \\
H2 & $\mathrm{t}=2,758 ;$ sig. $=0,004$ & H2 diterima \\
H3 & $\mathrm{t}=2,106 ;$ sig. $=0,004$ & H3 diterima \\
H4 & $\mathrm{F}=14,137$; sig. $=0,000$ & H4 diterima \\
\hline
\end{tabular}

Sumber: diolah penulis, SPSS, $n=75$

Hasil pada hipotesis 1 ini sejalan dengan dengan hasil penelitian terdahulu (Buli, 2017; Christian et al., 2021; Huhtala, Sihvonen, Frösén, Jaakkola, \& Tikkanen, 2014; Liao, Chang, Wu, \& Katrichis, 2011) dimana orientasi pasar berpengaruh terhadap kinerja usaha kedai kopi di PIK. Pemahaman untuk menganalisis pasar menjadi salah satu bagian penting dalam hal ini. Analisis pasar tidak hanya mempertimbangkan mengenai pesaing, tetapi juga memahami konsumen. Usaha kedai kopi seperti yang diketahui memiliki kecenderungan untuk terus beradaptasi dengan selera konsumen, seperti terkait dengan varian rasa, kemasan, sistem pembayaran dan sistem pengantaran. Hal-hal ini dapat menjadi sensitif bagi sebagian konsumen. Oleh karena itu, pelaku usaha kedai kopi perlu untuk memperhatikan aspekaspek yang terkait di dalamnya untuk membentuk pelanggan yang puas dan pelanggan yang loyal. Selain itu, faktor pesaing juga tidak bisa diremehkan. Perlunya menganalisis strategi pesaing juga secara tidak langsung dapat membantu pelaku usaha kedai kopi dalam memahami konsumen. Oleh karena itu, melakukan serangkaian analisis misalnya oberservasi dan perbandingan dapat membantu daya saing usaha kedai kopi. Selanjutnya, hasil penelitian ini menerima hipotesis 2. Hasil penelitian pada hipotesis ini mendukung hasil penelitian (Brouthers, Nakos, \& Dimitratos, 2014; Buli, 2017; Christian et al., 2021) dimana kinerja usaha kedai kopi di PIK pada penelitian ini dipengaruhi oleh orientasi kewirausahaan. Minat untuk menjadi wirausaha khususnya pada bidang kedai kopi dapat menjadi salah satu faktor penentu untuk membentuk kemampuan untuk menjalankan usaha, mulai dari membuat konsep usaha sampai mengeksekusi serangkaian strategi pemasaran kedai kopi yang dijalankan. Minat yang terus dikembangkan ini juga harus diselaraskan dengan tindakan untuk berani mengambil risiko terkait dengan strategi yang dilakukan. Tindakan mengambil risiko yang terkait dengan harga, rasa, maupun konsep atmosfer kedai kopi merupakan beberapa hal yang sering dikaitkan dengan aspek pengambilan risiko pada hal orientasi kewirausahaan. Pada hasil berikutnya juga menjelaskan bahwa hasil penelitian ini mendukung penelitian hasil penelitian Ketut, Satwika, Made, \& Kusuma (2018) dimana inovasi berpengaruh terhadap kinerja usaha kedai kopi di PIK pada penelitian ini. Seperti yang telah dijelaskan sebelumnya yaitu kemampuan pemasaran dapat membentuk inovasi-inovasi untuk menciptakan keunggulan bersaing. Kemampuan pemasaran yang baik dapat membentuk keunggulan bersaing yang dapat mempengaruhi kinerja usaha (Fitriah et al., 2019; Otnes, Ilhan, \& Kulkarni, 2012; Retnawati \& Retnaningsih, 2020). Kemampuan tim kedai kopi dalam menjaga konsistensi layanan membuat kopi dan menyajikan menu lainnya juga harus didasarkan pada hal-hal yang bersifat inovatif, misalnya dengan sistem antrian yang unik dan cepat. Selain itu juga, sistem pemesanan kopi dapat dikombinasikan dengan sistem lama dan juga sistem baru, misalnya penggunaan sistem pemesanan manual dan dikombinasikan dengan sistem digital. Selain itu, kemajuan teknologi pembayaran menjadikan sistem pembayaran non-tunai (cashless) menjadi metode pembayaran favorit bagi masyarakat saat ini. Oleh karena itu, pelaku usaha kedai kopi perlu untuk terus beradaptasi dan menyesuaikan kelengkapan sistem pembayaran yang ada di kedai kopi. Hal ini dapat membentuk kepuasan pelanggan dalam ketersediaan serangkaian alat pembayaran yang tersedia. 


\section{SIMPULAN}

Penelitian ini menyimpulkan bahwa keempat hipotesis diterima dimana orientasi pasar, orientasi kewirausahaan dan inovasi baik secara parsial maupun simultan. Hasil penelitian ini diharapkan berkontribusi untuk membantu para pelaku usaha kedai kopi di PIK dan daerah lainnya dalam membuat strategi dan mengambil keputusan yang mempengaruhi kinerja usaha. Kinerja bisnis dapat dimaksimalkan jika dapat memahami pasar melalui orientasi pasar. Selain itu juga dalam aspek ini perlu memperhatikan strategi pesaing dengan memahami kelebihan dan kekurangan pesaing. Di tambah lagi, perlu untuk melakukan pembaharuan pembaharuan baik produk, pelayanan, operasional, maupun sistem agar dapat memenuhi kepuasan konsumen dan meningkatkan kinerja bisnis. Bagi peneliti selanjutnya dapat menggunakan variabelvariabel tambahan lainnya yang tidak terdapat dalam penelitian ini dalam menentukan kinerja usaha, seperti kemampuan finansial usaha untuk bertahan maupun bersaing.

\section{DAFTAR PUSTAKA}

Annur, C. M. (2020). Konsumsi Kopi Domestik di Indonesia Periode 20142019 (ICO). Retrieved from Katadata website:

https://databoks.katadata.co.id/datapubli sh/2020/11/24/konsumsi-kopi-domestikdi-indonesia-terus-meningkat-selama-5tahun-terakhir\#

Brouthers, K. D., Nakos, G., \& Dimitratos, P. (2014). SME Entrepreneurial Orientation, International Performance, and the Moderating Role of Strategic Alliances. Entrepreneurship Theory and Practice, 39(5), 1-27. https://doi.org/10.1111/etap.12101

Buli, B. M. (2017). Entrepreneurial orientation, market orientation and performance of SMEs in the manufacturing industry: evidence from Ethiopian enterprises. Management Research Review, 40(3), 292-309. https://doi.org/10.1108/MRR-07-2016-
0173

Christian, M., Dewi, D., Rembulan, G. D., Indriyarti, E. R., Wibowo, S., \& Yuniarto, Y. (2021). Business Performance Determinants of Salted Fish Distribution in Kapuk During the COVID-19. Journal of Distribution Science, 19(6), 29-39. https://doi.org/10.15722/jds.19.6.20210 6.29

Dahwilani, D. M. (2019). Data dan Fakta Tren Menjamurnya Kedai Kopi Kekinian di Indonesia. Retrieved from inews website: https://www.inews.id/travel/kuliner/data -dan-fakta-tren-menjamurnya-kedaikopi-kekinian-di-indonesia

Fitriah, A. W., Rosdi, S. N., Rosli, M. M., Mustapha, N., Aziz, Z. A., Ibrahim, W. M. Y. W., ... Yaacob, A. A. (2019). The Effects of Marketing Mix on Small Fish Farming Business Performance. Revista Publicando, 6(19), 1-16.

Hair, J. F., Black, W. C., Babin, B. J., \& Anderson, R. E. (2014). Multivariate Data Analysis (7th ed.). Essex: Pearson Education Limited.

Huhtala, J.-P., Sihvonen, A., Frösén, J., Jaakkola, M., \& Tikkanen, H. (2014). Market orientation, innovation capability and business performance. Baltic Journal of Management, 9(2), 134-152. https://doi.org/10.1108/BJM03-2013-0044

Kempa, S., \& Setiawan, T. G. (2019). The Effect of Entrepreneurial Orientation on the Competitive Advantage through Strategic Entrepreneurship in the Cafe Business in Ambon. Petra International Journal of Business Studies (IJBS), 2(2), 109-118. https://doi.org/10.9744/ijbs.2.2.109-118

Ketut, N., Satwika, P., Made, N., \& Kusuma, W. (2018). Pengaruh Orientasi Pasar Serta Inovasi Terhadap Keunggulan Kompetitif dan Kinerja Bisnis. E-Jurnal Manajemen, 7(3), 1481-1509. https://doi.org/10.24843/EJMUNUD.20 18.v7.i03

Liao, S.-H., Chang, W.-J., Wu, C.-C., \& Katrichis, J. M. (2011). A survey of 
market orientation research (19952008). Industrial Marketing Management, 40, 301-310. https://doi.org/10.1016/j.indmarman.201 0.09 .003

Margasho, P. P., \& Susanto, E. H. (2021). Peran Social Media Terhadap Organizational Performance dan Entrepreneurial Orientation Pada Bisnis Coffee Shop di Jakarta Barat. 5(1), 88-93. https://doi.org/10.24912/jmbk.v5i1.1083 5

Nadhar, M., Tawe, A., \& Parawansa, D. A. (2017). The Effect of Work Motivation and Entrepreneurship Orientation on Business Performance through Entrepreneurial Commitments of Coffee Shops in Makassar. Econjournals, 7(1),
$470-474$.

Otnes, C. C., Ilhan, B. E., \& Kulkarni, A. (2012). The Language of Marketplace Rituals: Implications for Customer Experience Management. Journal of Retailing, 88(3), 367-383. https://doi.org/10.1016/j.jretai.2012.02.0 02

Retnawati, B. B., \& Retnaningsih, C. (2020). Role of Entrepreneurial Orientation and Market Orientation on Competitive Advantage Through Marketing Performance: The Study at MarineBased Food Processing Industry in Central Java. Advances in Economics, Business and Management Research, 135, 66-71. https://doi.org/10.2991/aebmr.k.200410. 011 